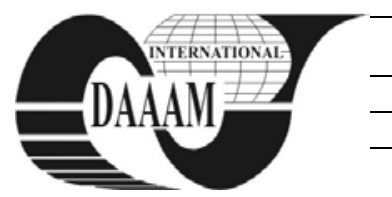

\title{
THE IMPLICATIONS OF MANAGERIAL ACCOUNTING IN STRATEGIC MANAGEMENT
}

\author{
ROTARU, V[iorel] H[oratiu]; VOICU, A[ndreea] R[aluca] \& KALAPIS, F[rantz]
}

\begin{abstract}
The paper is structured in three main parts: the first part regarding to introductive information: fundamentals, qualitative characteristics and the users of managerial accounting; the second part describes the methods used by managerial accounting in strategic management, and the third part refers to the influence of managerial accounting in strategic management and conclusions.
\end{abstract}

Key words: managerial accounting, strategic management, users, qualitative characteristics, objectives

\section{INTRODUCTION}

The objective of this work is to highlight how the managerial accounting influences the management strategies, taking into concern literature that does not link precisely the managerial accounting with the management strategies used.

The methods the authors used is literature constructive research and the result of this shows how managers can implement new managerial strategies resulted by the use of the information provided by managerial accounting.

The further research that we shall describe in another work is represented by the design of model that the managers should use to raise the performances of their entities using managerial accounting information, based not only of cost accounting.

\section{FUNDAMENTALS OF MANAGERIAL ACCOUNTING}

Managerial accounting is described as an integrating part of management that identifies, present and interpret the information used for: strategies formulation, planning and controlling of activities, decision taking, and optimization of used resources, information of users, and information of employees.

The above mentioned imply the participation of management to assure: the formulation of plans for long term objectives (strategic planning), the formulation of operational plans for short term (profit budgeting), actions of acquisition and finance (financial management) and the registration of these transactions (financial and cost accounting), corrective actions to assure the realization of plans (financial control) and report presentation regarding the system and operations (internal and managerial audit) (Brewer \& al., 2009).

The primary objective is the rise of data, analysis, processing, interpreting and communication of information for the use of entities' management in such a manner that the management can plan, decide and control better the operations.

\section{USERS OF MANAGERIAL ACCOUNTING}

As integrating part of management, managerial accounting has as a main user the management of the entity with its multiple informational needs that the entity tries to satisfy. The managerial accounting brings its contribution to the decisional system by cost analysis, budgeting and planning, the formulation of decisional judgements, analysis of resources use, analysis of price formation, control of all activities by specific methods and the supply of information regarding deviations and methods of correcting them, financial analysis of investment and so on (Garrison, 2008).

Another category of users of information generated by the managerial accounting is that of investors (shareholders), who are interested in the evolution of internal processes, their financial impact, and the analysis of efficiency of new investment projects of the entity, which fundaments their investment decision (Weygandt \& al., 2009).

In the same context, if the investment and financing process of exploitation is sustained by bank loan, the information of managerial accounting finds as a user also the bank that gives the loan (Brewer \& al., 2009).

The employees of the entity are also users of the managerial accounting. The utility of the managerial accounting is also manifested in several plans, such as: budgeting, controlling, employment, retirement, other employment facilities, internal statistics and so on. (Jiambalvo, 2009).

\section{QUALITATIVE CHARACTERISTICS OF MANAGERIAL ACCOUNTING INFORMATION}

There are four qualitative characteristics delivered the financial accounting published reports: intelligibility, relevance, reliability and comparability. If the information delivered by the financial accounting are mostly reliable and then relevant, in the case of managerial accounting we have an inverted report: relevance first and after reliability (Horngren \& al., 2008). In this context, referring to the content of each qualitative characteristic we mention:

- Intelligibility: For information to be intelligible it must be understood as easily possible by the users.

- Pertinence: an information is pertinent when it influences the economic decisions of users, facilitating the evaluation of past, present and future events by the users and confirming and correcting past evaluation.

- Reliability: Information is reliable when it does not contains errors or elements that lead to wrong interpretation, so the users can trust the fair image of the transaction.

- Comparability: represents the disponibility of the information to assure it's comparability in time and space with the purpose to reveal the trend of financial situations and its performance.

The dispute between relevance and reability in both financial and managerial accounting is determined by the method each of them understands to accomplish their mission. The financial accounting must deliver correct, fair, neutral, prudent and exhaustive information to the users in an environment in where it is not allowed for the decisions to develop under pertinence, and in a way uncertainty, with the risk of affecting the operativeness of information delivery, while the managerial accounting works with pertinent data, 
based on statistical approximation, sometimes incomplete, but that can fundament more operatively the management decision.

\section{METHODS USED BY MANAGERIAL ACCOUNTING IN STRATEGIC MANAGEMENT}

Cost accounting is a central element of managerial accounting and designed to provide a consistent and accurate application of how managerial costs are calculated and assigned to a product or service. The fundamental structure consists of four important elements (Horngren \& al., 2008):

- Cost-type accounting separates costs like labor, materials, and depreciation, followed by each cost account then being broken down into fixed and proportional costs along with the assignment of these cost accounts to cost centers.

- A cost center can be defined as an area of responsibility that is assigned to a manager who is held accountable for its performance. Primary Cost Centers are cost centers that provide output directly consumed by a saleable product or service is considered to be a primary cost center, related to the service or manufacturing process. Secondary Cost Centers are cost centers that incur costs but exist to support the functions of the primary cost centers. Typical secondary cost centers include: information technology (IT) services and; human resources (HR) areas that offer hiring and training functions.

- Product or Service cost accounting also referred to as Product Costing, is where all of the assigned costs that are product related will be collected. In cost accounting purest marginal form only proportional costs are assigned to products or services, but as indicated above a compromise is often struck by also assigning product-related fixed costs.

- Profitability management is the final component that completes the marginal costing system by adding in the revenues, cost-to-serve and common fixed costs along with the product/service cost accounting information discussed above.

\section{THE INFLUENCE OF MANAGERIAL ACCOUNTING IN STRETEGIC MANAGEMENT}

The entity strategy has as general purpose obtaining the best balance between: risks of project/entity, environment conditions, available resources, competition, and long term perspectives and so on (Jiambalvo, 2009).

Any business plan assumes a strategic vision from the management. In order to clarify, we present shortly three types of strategies that are influenced by the managerial accounting:

- Leader by cost strategy.

- Differentiation strategy.

- Focalization strategy: focalization by cost and by differentiation.

If an entity benefits of an important number of strengths, there are always two advantages that the entity can explore: low cost of the product or service offered and differentiation of the competition's products or services (Garrison, 2008).

The mixture of these two advantages with the specific of the activity of the business leads to three types of strategies. The first two strategies have their own characteristics and apply to large market segments, when the third refers to a particular market segment (Weygandt \& al., 2009).

Leader by cost strategy is the clearest strategy and refers to attaining the lowest cost in the business field with multiple market segments. In this case, sources of the competitive advantage are multiple, being represented by scale economy, preferential access to necessary row materials, property over used technology and so on. This strategy underlines the impact that cost accounting has, as a central element of managerial accounting. The primary cost center play a crucial role not only by measuring the performance, but firstly by determining the costs of the product or service, and evaluating in what manner these can be minimized, in order to gain the market segment with the lowest product or service possible (Garrison, 2008).

Differentiation strategy is applied when an entity wants to gain the statute of unique company in that certain business field by some characteristics of its offer, characteristics that are well appreciated by its clients. In order to attain its purpose the company choses those characteristics in such a manner to satisfy the demand of the clients in a unique way.

If an entity does not succeed in differentiating it is the same as all the others, fighting with competition based on the price of the products or services it offers. The potential of differentiation varies according with the type of activity developed. A business can differentiate by four main modalities: product differentiation, service differentiation, personnel differentiation, image differentiation. The modalities of differentiating are significant influenced by Secondary Cost Centers, IT services influence product or service differentiation and at the same time personnel and image differentiation is determined by HR areas.

Of course, there are secondary modalities of differentiation, as distribution or marketing plan and so on.

Focalization strategy is based on choosing a target segment, niche that is insufficiently explored, excluding those segments of the market that are already disputed and conquered. The focalization is realized by: cost, that has as objective obtaining a cost advantage in the target segment chosen or differentiation that has as purpose obtaining differentiation on the target segment (Weygandt \& al., 2009).

The niche must contain clients with special needs, so that the production system that characterizes the other market segments is differentiated by the other market segments.

Cost focalization underlines the cost differences in that segment and the focalization by differentiation highlights the insufficiency of service of the niche by the competitors.

\section{CONCLUSION}

As we have highlighted in this work, financial accounting has lost the ,war” with managerial accounting, because the first one refers to events that happened in the past and irrelevant while the second one accentuates the present and future events and management decisions (Horngren \& al., 2008).

In our opinion, managerial accounting is the key element that cannot be omitted when developing managerial strategies. Managerial accounting influences the decisions of management regarding strategies from the beginning, cost type accounting and primary cost centers that determine a low price as possible, secondary cost centers influence the differentiation using IT and HR, to the end by profitability management that shows how successful a management strategy is.

\section{REFERENCES}

Brewer, P.; Garrison, R. \& Noreen, E. (2009). Introduction to Managerial Accounting, McGraw-Hill, 978-0073527079, USA

Garrison, R. (2008). Managerial Accounting, Irwin/McGrawHill, 978-0073203065, USA

Horngren, T. C.; Harrison, T. W. \& Oliver, M. S. (2008). Financial and Managerial Accounting, Prentice Hall, 9780135045749, USA

Jiambalvo, J. (2009). Managerial Accounting, Wiley, 9780470333341, USA

Weygandt, J. J.; Kimmel P.D. \& Kieso D. E. (2009). Managerial Accounting: Tools for Business Decision Making, Wiley, 978-0470477144, USA 